\title{
Production of a gonadotropin-releasing hormone 2 receptor knockdown (GNRHR2 KD) swine line
}

\author{
A. T. Desaulniers $\cdot$ R. A. Cederberg - G. A. Mills • C. A. Lents • \\ B. R. White
}

Received: 30 August 2016/Accepted: 11 May 2017/Published online: 22 May 2017

(C) The Author(s) 2017. This article is an open access publication

\begin{abstract}
Swine are the only livestock species that produce both the second mammalian isoform of gonadotropin-releasing hormone (GNRH2) and its receptor (GNRHR2). Previously, we reported that
\end{abstract}

Mention of trade names or commercial products in this publication is solely for the purpose of providing specific information and does not imply recommendation or endorsement by the U.S. Department of Agriculture.

The U.S. Department of Agriculture (USDA) prohibits discrimination in all its programs and activities on the basis of race, color, national origin, age, disability, and where applicable, sex, marital status, familial status, parental status, religion, sexual orientation, genetic information, political beliefs, reprisal, or because all or part of an individual's income is derived from any public assistance program (Not all prohibited bases apply to all programs). Persons with disabilities who require alternative means for communication of program information (Braille, large print, audiotape, etc.) should contact USDA's TARGET Center at (202) 720-2600 (voice and TDD). To file a complaint of discrimination, write to USDA, Director, Office of Civil Rights, 1400 Independence Avenue, S.W., Washington, D.C. 20250-9410, or call (800) 795-3272 (voice) or (202) 720-6382 (TDD). USDA is an equal opportunity provider and employer.

A. T. Desaulniers and R. A. Cederberg contributed equally to this work.

A. T. Desaulniers - R. A. Cederberg ·

G. A. Mills · B. R. White $(\varangle)$

Department of Animal Science, University of Nebraska-

Lincoln, A224j Animal Science Building, 3940 Fair

Street, Lincoln, NE 68583-0908, USA

e-mail: bwhite2@unl.edu
GNRH2 and GNRHR2 mediate LH-independent testosterone secretion from porcine testes. To further explore this ligand-receptor complex, a pig model with reduced GNRHR2 expression was developed. Small hairpin RNA sequences targeting porcine GNRHR2 were subcloned into a lentiviral-based vector, lentiviral particles were generated and microinjected into the perivitelline space of zygotes, and embryos were transferred into a recipient. One GNRHR2 knockdown (KD) female was born that subsequently produced 80 piglets from 6 litters with 46 hemizygous progeny (57\% transgenic). Hemizygous GNRHR2 KD $(\mathrm{n}=10)$ and littermate control $(\mathrm{n}=7)$ males were monitored at 40,100, 150, 190, 225 and 300 days of age; body weight and testis size were measured and serum was isolated and assayed for testosterone and luteinizing hormone (LH) concentrations. Body weight of GNRHR2 KD boars was not different from littermate controls $(P=0.14)$, but testes were smaller $\left(P<0.05 ; 331.8\right.$ vs. $374.8 \mathrm{~cm}^{3}$, respectively). Testosterone concentrations tended $(P=0.06)$ to be reduced in GNRHR2 KD $(1.6 \mathrm{ng} / \mathrm{ml})$ compared to littermate control $(4.2 \mathrm{ng} / \mathrm{ml})$ males, but LH levels were similar $(P=0.47)$. The abundance of GNRHR 2 mRNA was reduced $(P<0.001)$ by $69 \%$ in testicular tissue from

C. A. Lents

USDA, Agricultural Research Service, U.S. Meat Animal Research Center, Clay Center, NE 68933-0166, USA 
mature GNRHR2 KD $(\mathrm{n}=5)$ versus littermate control $(n=4)$ animals. These swine represent the first genetically-engineered model to elucidate the function of GNRH2 and its receptor in mammals.

Keywords GNRH2 - GNRHR2 - Porcine ·

Transgenic · Testosterone - Testis · Gene knockdown · shRNA

\section{Introduction}

Gonadotropin-releasing hormone (GNRH1; pGluHis-Trp-Ser-Tyr-Gly-Leu-Arg-Pro-Gly) is well-regarded as the master regulator of reproduction in mammals. A second GnRH isoform (GNRH2; pGluHis-Trp-Ser-His-Gly-Trp-Tyr-Pro-Gly) has also been identified in mammals (White et al. 1998). Expression of GNRH2 is ubiquitous (Neill 2002) and is most abundant in tissues outside of the brain (White et al. 1998), suggesting a divergent role from GNRH1. Indeed, GNRH2 is a poor stimulator of gonadotropin release; GNRH2-induced secretion of luteinizing hormone (LH) and follicle-stimulating hormone (FSH) is about $10 \%$ that of GNRH1 (Millar et al. 1986).

A 7-transmembrane, G-protein-coupled receptor specific for GNRH2 (GNRHR2) has also been identified in mammals (Millar et al. 2001; Neill et al. 2001). Interestingly, GNRH1 receptor (GNRHR) and GNRHR2 are quite different; their homology is only about $40 \%$ and GNRHR2 has an intracytoplasmic tail which GNRHR lacks (Millar 2003). Like its ligand, the GNRHR2 gene is also expressed ubiquitously, including extra-pituitary reproductive tissues (Millar et al. 2001; Neill et al. 2001). Interestingly, GNRHR2 mRNA levels were highest in the marmoset testis compared to 31 other organs (Millar et al. 2001). However, most mammalian species are unable to produce a functional GNRHR2 due to gene deletions or gene coding errors (Gault et al. 2004; Millar 2003; Morgan et al. 2003; Neill et al. 2002a; Pawson et al. 2003). In fact, the pig is the only livestock species to maintain the appropriate sequence to encode a fulllength GNRHR2 (Stewart et al. 2009). Furthermore, this receptor is considered functional since exogenous GNRH2 treatment stimulated inositol triphosphate production from COS cells overexpressing the porcine GNRHR2 (Neill et al. 2002b).

Studies in boars indirectly suggested that a testicular GnRH isoform mediates steroidogenesis within the porcine testis (Bowen et al. 2006; Wise et al. 2000; Zanella et al. 2000). However, GNRHR is absent in swine testes (Zanella et al. 2000); therefore, we hypothesized that the results of the aforementioned studies could be ascribed to GNRHR2. In support of this hypothesis, the GNRHR2 gene promoter is active in a swine testis-derived (ST) cell line (Brauer et al. 2016) and both GNRH2 and GNRHR2 protein are abundantly produced within the boar testis (Desaulniers et al. 2015). We also demonstrated that GNRHR2 immunolocalized to porcine Leydig cells and exogenous GNRH2 treatment stimulated LHindependent testosterone secretion from testes of boars (Desaulniers et al. 2015). These data suggest that swine maintain a unique testicular GNRH2-GNRHR2 system capable of regulating testosterone secretion in a paracrine manner that is independent from the classical androgen stimulator, LH. However, the function and cellular mechanisms of GNRH2-mediated testosterone secretion remain unknown. Thus, we developed a GNRHR2 knockdown (KD) swine line to further examine the role of GNRH2 and its receptor in the boar testis.

\section{Materials and methods}

Animals

White crossbred pigs from the University of NebraskaLincoln (UNL) Agricultural Research and Development Center (ARDC) swine unit (Mead, NE) were used to generate the founder animal. Yorkshire boar semen, purchased from Swine Genetics International (Cambridge, IA), was used to produce progeny from the founder female. Farrowing and subsequent housing occurred within the UNL Animal Science Building (Lincoln, NE). Pre-pubertal pigs were group housed with ad libitum access to feed and water. Adult pigs were housed individually with ad libitum access to water and fed approximately $2.5 \mathrm{~kg}$ of feed daily. All diets were formulated to meet National Research Council guidelines for each stage of production. 
Vector preparation, production of lentiviral

particles and ST cell transduction

Utilizing oligomer design software (Clontech, Mountain View, CA), two potential target small hairpin (shRNA) sequences, shRNA1 (TGGCTACTCAGTTTCCTTC) and shRNA2 (CTGTCATGACCATCTGCTA), specific to the porcine GNRHR2 (NCBI accession number NM_001001639.2) were identified and subcloned into a lentiviral-based, pLVX-shRNA2 vector (Cat \# 632179; Clontech) that provides both ubiquitous shRNA and fluorescent ZsGreen1 co-expression. Neither shRNA sequences matched other genes in the porcine genome including GNRHR (NCBI accession number JN120792.1). The shRNA expression was driven by the human U6 promoter, whereas ZsGreen1 expression was controlled by the cytomegalovirus (CMV) promoter. Lentiviral particles were produced from each shRNA vector, as well as a control vector, by transfection with Fugene6 (Promega, Madison, WI) and the Lenti-X HTX Packaging Mix into Lenti-X 293T cells (Clontech). Briefly, $4 \times 10^{6}$ cells were plated in $10 \mathrm{~cm}$ dishes at approximately $70 \%$ confluency, and cells were transfected with $5 \mu \mathrm{g}$ of vector, $15 \mu \mathrm{l}$ of Lenti-X HTX Packaging Mix (Clontech) and $30 \mu \mathrm{l}$ Fugene6 (Promega). Approximately 48 h later, particles were harvested and concentrated (100X) with Lenti-X Concentrator (Clontech) according to the manufacturer's instructions. Titrations of viral particles were performed by infecting swine testisderived (ST) cells (CRL-1746; ATCC, Manassas, VA) with serial dilutions of lentivirus and counting fluorescent cells to determine infectious units (IU)/ $\mathrm{ml}$.

The ability of shRNA1 and shRNA2 lentiviral particles to ablate porcine GNRHR2 mRNA levels was tested in ST cells. The day prior to transduction, ST cells $\left(1.2 \times 10^{6}\right.$ cells/plate $)$ were plated in $100 \mathrm{~mm}$ plates containing high-glucose Dulbecco's Modified Eagle's Medium (Mediatech, Herndon, VA) supplemented with $10 \%$ FBS, $2 \mathrm{mM}$ glutamine, $100 \mathrm{U} / \mathrm{ml}$ penicillin, and $100 \mu \mathrm{g} / \mathrm{ml}$ streptomycin sulfate (Gibco, Grand Island, NY). Cells were transduced with $1.44 \times 10^{7}$ viral particles per plate for $48 \mathrm{~h}$. At $48 \mathrm{~h}$ post-transduction, RNA was isolated from ST cells with TRIzol (1.5 ml/plate; Invitrogen, Grand Island, NY) per manufacturer's instructions and stored at $-20{ }^{\circ} \mathrm{C}$ until reverse transcription (RT).
Quantitative PCR

Ribonucleic acid from ST cells was DNase treated with RQ1 (Promega) and quantitated using a Nanodrop spectrophotometer (NanoDrop Technologies, Inc., Wilmington, DE). The RNA was reverse transcribed into cDNA with M-MLV (Promega) and random hexamers (Promega). The PCR amplification of GNRHR2 was performed using forward (F-CCCCG GACAAGGAAGGG) and reverse (R-AAGGAGCG ACGGAGGGTCAA) primers (Integrated DNA Technologies, Coralville, Iowa) as well as a FAM labeled TaqMan MGB probe (ATGATGCCCCTGCCGG; Applied Biosystems, Foster City, CA). Quantitative PCR was performed on cDNA samples with an ABI 7900 HT instrument (Applied Biosystems). The amplification protocol included an initial $50{ }^{\circ} \mathrm{C}$ step for $2 \mathrm{~min}$ followed by $95{ }^{\circ} \mathrm{C}$ for $10 \mathrm{~min}$ and then alternating temperatures between $95{ }^{\circ} \mathrm{C}$ for $15 \mathrm{~s}$ and $60{ }^{\circ} \mathrm{C}$ for $1 \mathrm{~min}$, repeated 50 times. The housekeeping gene was eukaryotic RNA18S (kit \#4319413E; VIC/ MGB Probe; Applied Biosystems). Cycling conditions for RNA18S were the same as those described for GNRHR2. Internal controls included samples prepared without reverse transcriptase (no RT control) and without cDNA (water only control).

Generation of transgenic pigs

RNA interference (RNAi) has successfully been employed to impair gene expression in a variety of mammalian cells (Dann 2007; Park 2007; Roelz et al. 2010; Rubinson et al. 2003). Transducing zygotes via viral particles has generated transgenic mice (Miao et al. 2011; Rubinson et al. 2003), rats (Dann 2007), chickens (McGrew et al. 2004), goats (Golding et al. 2006) and pigs (Hofmann et al. 2003; Whitelaw et al. 2004). In this study, we utilized lentiviral particles and RNAi to produce a transgenic model to study the function of GNRHR2 in swine. Briefly, zygotes $(\mathrm{n}=50$ ) were surgically flushed from the oviduct of one superovulated, white crossbred donor sow. Embryos were collected in Beltsville embryo culture medium (BECM; $19.3 \mathrm{mM}$ sodium lactate, $2.13 \mathrm{mM}$ calcium lactate, $90 \mathrm{mM}$ sodium chloride, $4.83 \mathrm{mM}$ potassium chloride, $0.54 \mathrm{mM}$ magnesium chloride, $2.14 \mathrm{mM}$ sodium bicarbonate, $10.91 \mathrm{mM}$ Hepes free acid, $0.55 \mathrm{mM}$ glucose, $11 \mathrm{mM}$ mannitol, $1 \mathrm{mM} \mathrm{L-}$ glutamine, $7 \mathrm{mM}$ taurine, $0.27 \mathrm{mM}$ sodium pyruvate, 
$80 \mathrm{mM}$ EDTA free acid, $0.001 \%$ phenol red, $1 \%$ BSA, $50 \mu \mathrm{g}$ gentamycin sulfate; Dobrinsky et al. 1996) and cultured briefly $(1 \mathrm{~h})$ prior to microinjection. All reagents for BECM were purchased from Sigma (St. Louis, MO) except L-glutamine, EDTA and gentamycin sulfate (Gibco). Embryos were microinjected with lentiviral particles according to a protocol generously shared by Dr. Charles Long (Texas A\&M University, College Station, TX). Briefly, embryos were placed in $100 \mu \mathrm{l}$ microdrops of BECM $+200 \mathrm{mM}$ sucrose (Fisher, Fair Lawn, NJ) on micromanipulation plates $(100 \times 15 \mathrm{~mm}$ petri dish; VWR International, Batavia, IL) layered with embryo-tested mineral oil (M8410; Sigma). Sucrose was utilized to retract the cytoplasm from the zona pellucida to facilitate microinjection into the perivitelline space (Miao et al. 2011). Using a holding pipet (VacuTip; ID $=15 \mu \mathrm{m}$; OD $=100 \mu \mathrm{m}$; Eppendorf, AF, Hamburg, Germany) and an intracytoplasmic sperm injection (ICSI) needle (TransferTip-F; $\mathrm{ID}=4 \mu \mathrm{m} ; \mathrm{OD}=7 \mu \mathrm{m}$; Eppendorf) backloaded with $5 \mu \mathrm{l}$ of lentiviral particles $\left(1.15 \times 10^{9} \mathrm{IU} / \mathrm{ml}\right)$, each embryo was microinjected within the perivitelline space for $30 \mathrm{~s}$ using the manual setting ( $\mathrm{pi}=150 \mathrm{hPa}$; $\mathrm{pf}=0 \mathrm{hPa})$ on the Eppendorf Femtojet injection system with a Nikon diaphot inverted microscope (Melville, NY). A total of 40 microinjected zygotes were surgically transferred into the oviduct of one synchronized recipient female, which was allowed to gestate to term.

\section{Confirmation of transgene integration}

Upon birth of piglets from the recipient, expression of ZsGreen1 was examined with a UV light and a Roscolux \#15 (deep straw; Rosco, Port Chester, NY) filter. In addition, genomic DNA was isolated from tail samples using a DNeasy Blood and Tissue Kit (Qiagen, Valencia, CA). Transgene integration was evaluated via conventional PCR using primers designed to amplify a portion of the human U6 promoter driving the shRNA (F-GAGGGCCTATTTCCCATGAT; R-G ATCCTCGTCCTTTCCACAA), a region from the U6 promoter to the multiple cloning site (U6/MCS) to verify incorporation of the shRNA sequence (F- GA GGGCCTATTTCCCATGAT; R-GGGCGTACTTG GCATATGAT), and a portion of the ZsGreen 1 coding sequence (F-CTGCATGTACCACGAGTCCA; R-GT CAGCTTGTGCTGGATGAA). The Philisa Thermocycler (Streck Inc., Omaha, NE) was used for rapid evaluation of samples with the following conditions for both the U6 and ZsGreen1 reactions: 1 X Taq Buffer A (Fisher) with a final concentration of $3.0 \mathrm{mM} \mathrm{MgCl}$, $200 \mu \mathrm{M}$ dNTPs, $400 \mathrm{nM}$ of each primer and $1.25 \mathrm{U}$ of Taq DNA Polymerase (Fisher). Cycling conditions were $95{ }^{\circ} \mathrm{C}$ for $60 \mathrm{~s}$, followed by 35 cycles of $95{ }^{\circ} \mathrm{C}$ for $5 \mathrm{~s}, 55^{\circ} \mathrm{C}$ for $5 \mathrm{~s}$ and $72{ }^{\circ} \mathrm{C}$ for $10 \mathrm{~s}$ and a final extension of $72{ }^{\circ} \mathrm{C}$ for $20 \mathrm{~s}$. The U6/MCS PCR reaction conditions were the same, however the cycling conditions were as follows: $95^{\circ} \mathrm{C}$ for $60 \mathrm{~s}$, followed by 35 cycles of $95{ }^{\circ} \mathrm{C}$ for $10 \mathrm{~s}, 56{ }^{\circ} \mathrm{C}$ for $10 \mathrm{~s}$ and $72{ }^{\circ} \mathrm{C}$ for $15 \mathrm{~s}$ and a final extension of $72{ }^{\circ} \mathrm{C}$ for $30 \mathrm{~s}$. The resultant PCR products were subjected to electrophoresis on a $1 \%$ agarose gel.

Inverse PCR was performed as described previously (Cederberg et al. 2015) to determine the location and number of integration sites. Briefly, genomic DNA was digested with $\mathrm{XbaI}$ or HindIII and fragments were self-ligated with a high concentration of T4 DNA ligase $(0.1 \mathrm{IU} / \mu \mathrm{l}$; Thermo Scientific Fermentas, Pittsburg, PA) and a low concentration $(2 \mu \mathrm{g} / \mu \mathrm{l})$ of DNA. PCR was performed on the circularized DNA with primers selected from the integrated pLVX-shRNA2 sequence (XbaI-F: GAGATCCCTCAGACCCTTTT, XbaI-R: GTTGCGTCAGCAAACACAGT; HindIIIF: GAGCCCTCAGATCCTGCATA, HindIII-R: AG CACCATCCAAAGGTCAGT) and in reverse orientation of typical primers. Resultant $P C R$ products were sequenced with nested primers for $\mathrm{X} b a \mathrm{I}$ (TCCCTCAGACCCTTTTAGTCA) and HindIII (CTGGCC CTGGTGTGTAGTTC) derived products at the University of Nebraska Medical Center Genomic Core Facility (Omaha, NE).

\section{Characterization of GNRHR2 KD swine line}

At 40,100, 150, 190, 225 and 300 days of age, testis size of GNRHR2 KD $(\mathrm{n}=10)$ and littermate control $(n=7)$ boars was measured using digital calipers. Predicted testis volume was calculated using the following equation: Volume $=3 / 4(\pi)(\mathrm{L} / 2)(\mathrm{W} / 2)^{2}$, where $\mathrm{L}=$ testis length and $\mathrm{W}=$ testis width (Bailey et al. 1998). Body weight was recorded and blood samples were collected via jugular venipuncture. Blood samples were allowed to clot at $4{ }^{\circ} \mathrm{C}$ overnight before centrifugation $(2000 \times g)$. Serum was collected and stored at $-20{ }^{\circ} \mathrm{C}$ until use. Transgenic $(\mathrm{n}=5)$ and littermate control boars $(\mathrm{n}=4)$ were subsequently euthanized ( $717 \pm 24$ days of age) by 
intravenous injection of Fatal-Plus Solution $(1 \mathrm{mg} /$ $4.5 \mathrm{~kg}$; pentobarbital; Vortech Pharmaceuticals, Dearborn, MI). Testicular tissue was collected immediately and stored in RNAlater (100 mg/ml; Qiagen) at $-20{ }^{\circ} \mathrm{C}$ for subsequent mRNA analysis.

\section{Radioimmunoassay}

Unextracted serum was analyzed in duplicate to quantify concentrations of testosterone by a double antibody radioimmunoassay (RIA) kit (cat \# 07-189102; MP Biomedicals, Aurora, OH), in accordance with manufacturer's instructions. Additional standards $(0.03$ and $0.16 \mathrm{ng} / \mathrm{ml})$ were added to reach the sensitivity of the assay $(0.03 \mathrm{ng} / \mathrm{ml})$. The intra- and inter-assay coefficients of variation (CV) were 6.5 and $7.7 \%$, respectively. Concentrations of $\mathrm{LH}$ were determined by RIA at the Colorado State University Reproductive Endocrinology Laboratory (Fort Collins, $\mathrm{CO}$ ). The intra- and inter-assay $\mathrm{CV}$ were 2.7 and $6.2 \%$, respectively.

\section{Digital droplet PCR}

Digital droplet PCR (ddPCR) was used to quantify the abundance of GNRHR2 mRNA in testes of transgenic $(\mathrm{n}=5)$ and control $(\mathrm{n}=4)$ boars. Samples were removed from RNAlater and homogenized in TRIzol (1 ml; Invitrogen) with a Tissue Tearor (Biospec Products Inc., Bartlesville, OK). Total RNA was subsequently extracted using standard procedures with chloroform and isopropyl alcohol. Ribonucleic acid was DNAse treated, quantitated on a Nanodrop spectrophotometer (NanoDrop Technologies, Inc.) and reverse transcribed ( $2 \mathrm{ug}$ ) into cDNA as described above.

To quantify GNRHR2 transcript levels, specific primers (Integrated DNA Technologies) and a FAM labeled TaqMan MGB probe (Applied Biosystems) were utilized as described above. Each reaction contained $1 \mu \mathrm{l}$ of the cDNA template (undiluted), $900 \mathrm{nM}$ of each primer, $250 \mathrm{nM}$ of the probe and ddPCR Supermix for Probes (Bio-Rad, Richmond, CA). Droplets were generated using the QX200 Droplet Generator (Bio-Rad) according to manufacturer's instructions. A C1000 Touch Thermal Cycler (Bio-Rad) was utilized with the following conditions: $95{ }^{\circ} \mathrm{C}$ for $5 \mathrm{~min}$ (enzyme activation), $95^{\circ} \mathrm{C}$ for $30 \mathrm{~s}$ (denaturation) followed by $60{ }^{\circ} \mathrm{C}$ for $1 \mathrm{~min}$ (annealing/extension; 40 cycles), $4{ }^{\circ} \mathrm{C}$ for $5 \mathrm{~min}$ and $90{ }^{\circ} \mathrm{C}$ for $5 \mathrm{~min}$ (signal stabilization). Droplets were read via the QX200 droplet reader (Bio-Rad) and analyzed using Quantasoft Software (Bio-Rad). The housekeeping gene utilized was $A C T B$; each reaction contained $1 \mu \mathrm{l}$ of the cDNA template (diluted 1:100), $100 \mathrm{nM}$ of each primer (F-AACTCCATCATGAAGTGCGACG; R-GATCCACATCTGCTGGAAGG) and EvaGreen ddPCR Supermix (BioRad). Cycling conditions for $A C T B$ were the same as those described for $G N R H R 2$ reactions.

Statistical analysis

Statistical analyses were performed using the Statistical Analysis System (SAS; Cary, NC). The mRNA data was analyzed using the MIXED procedure of SAS with lentiviral treatment or swine line included in the model as the fixed effect. When applicable, litter was included in the model as a random effect. The experimental unit was either plate or animal. When a significant treatment effect $(P \leq 0.05)$ was observed, pair-wise comparisons were made using the TukeyKramer test.

Hormone data, predicted testis volume and body weight were analyzed via the MIXED procedure of SAS using a model that included line (transgenic or control), age (days), and their interaction as fixed effects. Animal was the experimental unit and litter was included as a random effect. Age was used as the repeated measure with animal as the subject. Degrees of freedom for the pooled error term were calculated using the Satterthwaite approximation. Based on the Akaike's information criterion, a heterogeneous autoregressive function with lag equal to 1 was used to model the covariance structure for the repeated measures. When analyzing predicted testis volume, body weight was found to be a significant covariable $(P=0.02)$ and therefore was included in the statistical model. In contrast, predicted testis volume was not found to be a significant covariable for testosterone concentration, therefore it was excluded from the analysis. A single $\mathrm{LH}$ value (control boar; 150 days of age) was found to be an outlier ( \pm 2 standard deviations from the mean) so it was excluded from the dataset. A $P$ value of $\leq 0.05$ was considered significant, whereas a $P$ value of $\leq 0.10$ was considered a tendency. Results are presented as least squares means (LSMEANS) \pm the standard error of the mean (SEM). 


\section{Results and discussion}

Previously, our laboratory detected GNRHR2 protein within the swine testis (Desaulniers et al. 2015) as well as the ST cell line (data not shown). Therefore, we transduced ST cells with lentiviral particles derived from a vector (Fig. 1a) overexpressing shRNA specific to the GNRHR2 (shRNA1 and shRNA2) in order to test the efficacy of lentiviral particles prior to production of a transgenic pig line. Lentiviral particles containing either shRNA1 or shRNA2 sequences significantly reduced GNRHR2 mRNA levels (95 and $99 \%$, respectively) compared to control particles $(P<0.05$; Fig. 1b). After the efficiency of the lentiviral particles was confirmed in vitro, lentiviral particles derived from the vector overexpressing shRNA2 were microinjected into porcine zygotes before transfer into a synchronized recipient female.

The recipient gestated for 113 days and farrowed 5 healthy, live piglets ( 2 males and 3 females). One female exhibited ZsGreen1 fluorescence of the skin (20\% efficiency), indicative of successful transgene integration and expression. Transgene integration was confirmed via conventional PCR using primers designed to amplify the human U6 promoter driving the shRNA, ZsGreen1, and a region from the U6 promoter to the multiple cloning site (U6/MCS) to verify incorporation of the shRNA sequence (Fig. 1c). Sequence analysis of products from inverse PCR procedures revealed that a single integration site was present on chromosome 14, aligning with clone NW_003612067.1 with $99 \%$ identity and matching identities 448,946-448,372. Thus, the transgene integrated in a non-coding region between the Sorbin and SH3 Domain Containing 1 (SORBS1) and the Aldehyde Dehydrogenase 18 Family, Member A1 (ALDH18A1) genes (Fig. 1d). This animal was retained to generate the GNRHR2 KD swine line.

The founder gilt was bred at her third post-pubertal estrus to a commercial white crossbred boar and
A pLVX-shRNA2
RRE CPPT/CTS MCS

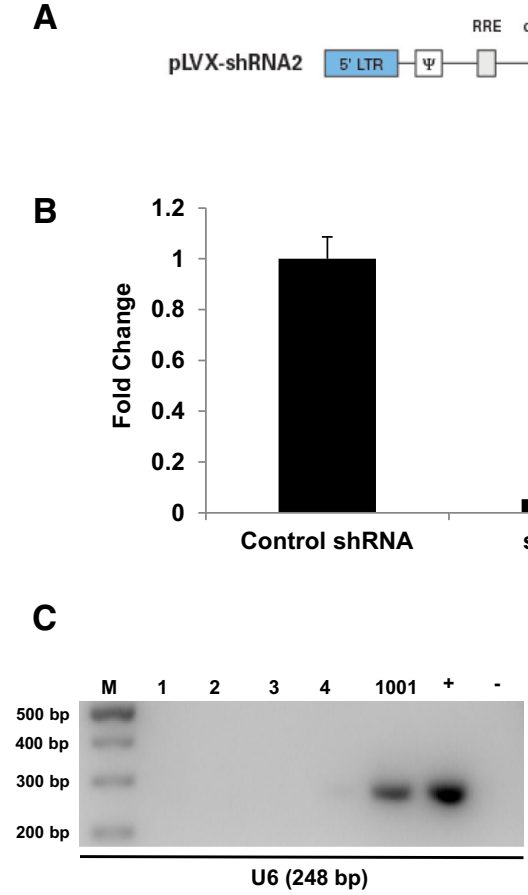

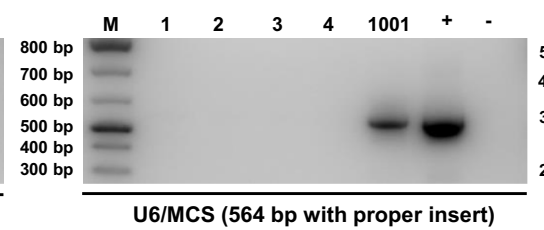

D

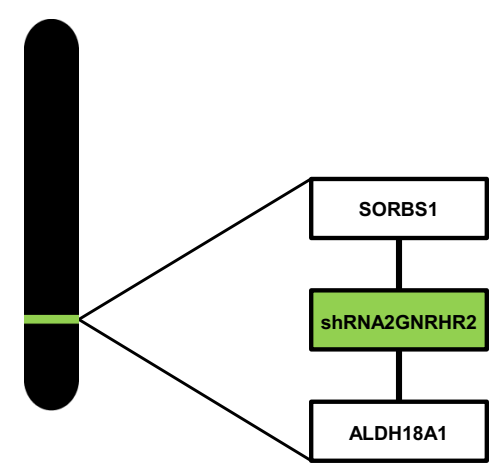

Fig. 1 Generation of GNRHR2 KD pigs. a Schematic representation of the construct used for lentiviral particle generation. b GNRHR2 mRNA levels in ST cells following transduction with lentiviral particles containing shRNA specific for the GNRHR2 or control. Data are presented as the LSMEANS \pm SEM. $* P<0.05$. c PCR detection of GNRHR2 KD founder (\#1001) and control littermates (\#1-4). M, DNA ladder; +, positive plasmid control; - , negative control. d Sequencing analysis of inverse PCR products revealed that a single integration site was present on chromosome 14, located between the Sorbin and SH3 Domain Containing 1 (SORBS1) and the Aldehyde Dehydrogenase 18 Family, Member A1 (ALDH18A1) genes 
subsequently gestated to term. She farrowed 15 healthy piglets with 5 progeny exhibiting ZsGreen 1 expression ( 3 males and 2 females). The founder female subsequently produced a total of 80 piglets from 6 litters ( 6 different white crossbred sires) with 46 transgenic piglets (57\%), confirming germline transmission of the transgene and providing further evidence for a single integration site.

During pubertal development, hemizygous GNRHR2 KD $(\mathrm{n}=10)$ and littermate control $(n=7)$ boars from 4 litters were monitored for differences in body weight, predicted testis volume and serum hormone (testosterone and $\mathrm{LH}$ ) concentrations. Body weight was not affected by line $(P=0.14)$ or line by age interaction $(P=0.61)$, indicating that GNRHR2 KD and littermate control boars had a similar body weight during pubertal
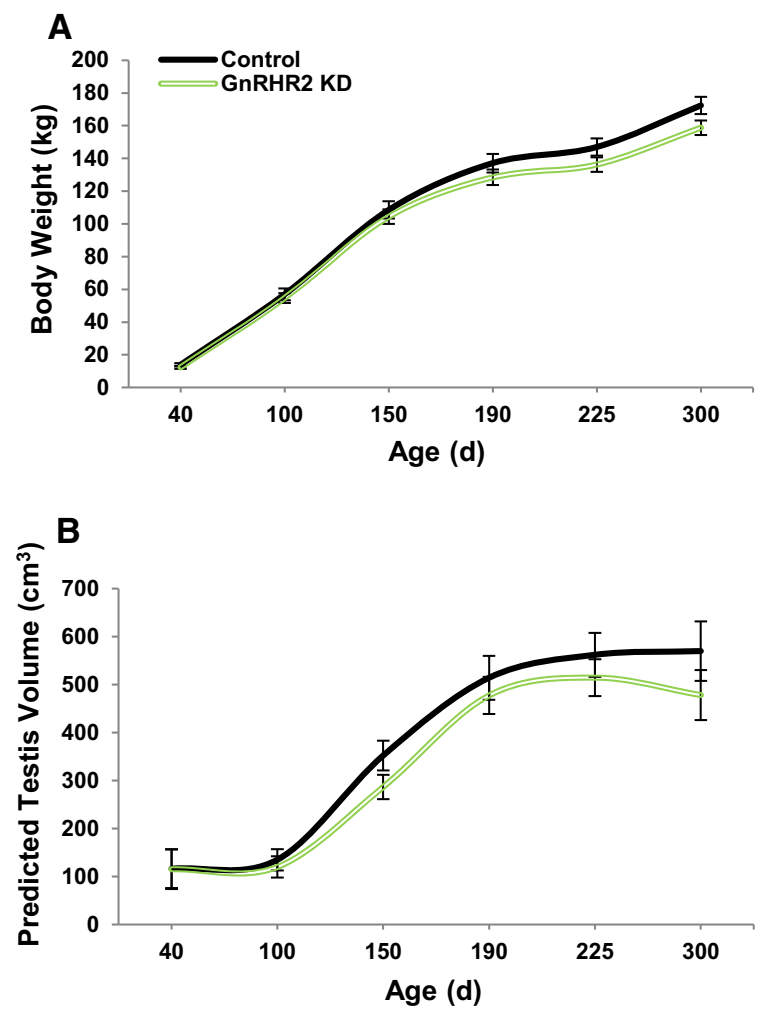

Fig. 2 GNRHR2 KD swine $(\mathrm{n}=10)$ have smaller testes and reduced serum testosterone concentrations compared to littermate control $(\mathrm{n}=7)$ animals during pubertal development. At 40, 100, 150, 190, 225 and 300 days of age, blood was collected and body weight and predicted testis volume were determined. Serum testosterone and LH concentrations were determined by radioimmunoassay. Data are presented as the development (Fig. 2a). Despite a similar body weight, there was a line effect $(P<0.05)$ for predicted testis volume. Predicted testis volume of GNRHR2 KD boars was smaller $\left(331.77 \pm 13.9 \mathrm{~cm}^{3}\right)$ overall during pubertal development than for littermate controls (374.75 $\pm 17.17 \mathrm{~cm}^{3}$; Fig. 2b), suggesting a defect in testis development. As expected, there was an effect of age on predicted testis volume $(P<0.0001)$ but there was no line by age interaction $(P=0.39$; Fig. 2b).

There was no line by age interaction $(P=0.39$; Fig. 2c) on concentration of testosterone in serum. However, there was a tendency for a line effect $(P=0.06$; Fig. $2 \mathrm{c})$ as well as an expected effect of age $(P<0.0001 ;$ Fig. 2 c). GNRHR2 KD boars tended to have reduced concentrations of testosterone in serum overall during pubertal development
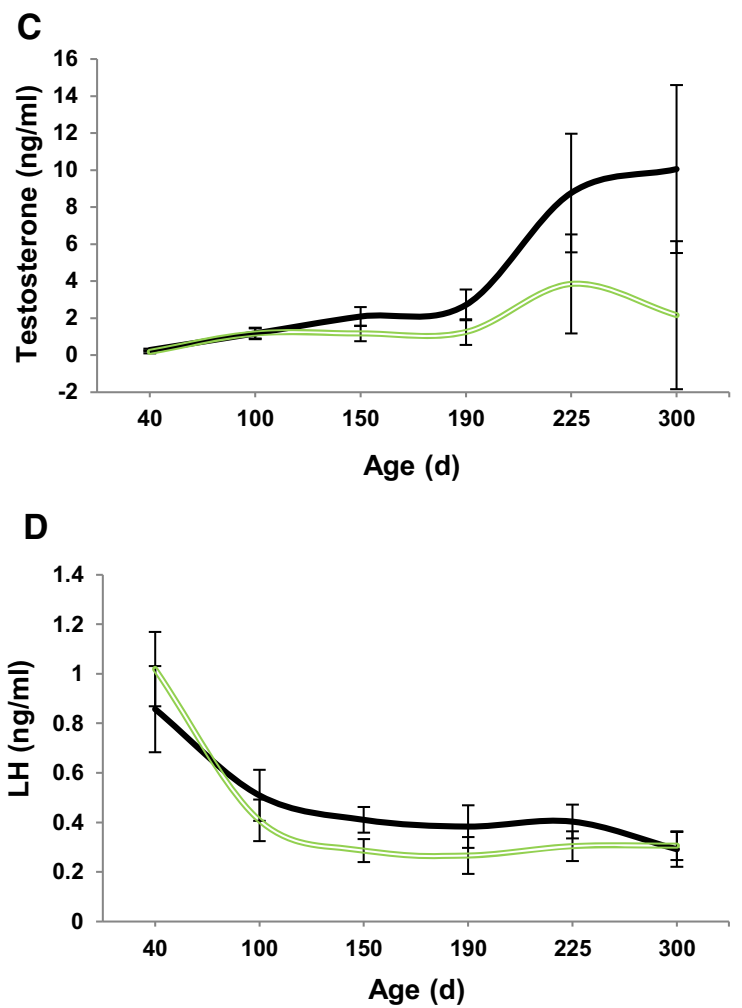

LSMEANS \pm SEM. a Body weight: Line, $P=0.14$; Time, $P<0.0001$; Line $\times$ Time, $P=0.61$. Predicted testis volume (b): Line, $P=0.05$; Time, $P<0.0001 ; \quad$ Line $\times$ Time, $P=0.39$. Testosterone (c), Line, $P=0.06$; Time, $P<0.0001 ;$ Line $\times$ Time, $P=0.39$. Luteinizing hormone (d), Line, $P=0.47$; Time, $P<0.0001 ; \quad$ Line $\times$ Time, $P=0.52$ 
$(1.63 \pm 0.87 \mathrm{ng} / \mathrm{ml})$ compared with littermate control animals $(4.18 \pm 1.0 \mathrm{ng} / \mathrm{ml} ; P=0.06)$. Despite differences in testosterone secretion, LH concentrations were similar between GNRHR2 KD and control boars during development ( $P=0.47$; Fig. 2 d). To confirm knockdown in these animals, transgenic $(\mathrm{n}=5)$ and control $(\mathrm{n}=4)$ testicular tissue was collected and GNRHR2 mRNA abundance was determined via ddPCR. Testicular GNRHR2 mRNA levels in transgenic boars were approximately $69 \%$ less than littermate control boars $(P<0.001$; Fig. 3$)$, confirming the successful production of a GNRHR2 KD swine line. These findings are consistent with our previous report demonstrating that GNRH2 stimulates testosterone secretion in vivo, without the classic preceding rise in serum LH levels associated with GNRH1 (Desaulniers et al. 2015) and strengthen our hypothesis that GNRHR2 is involved in testicular steroidogenesis within swine testes. However, since LH and testosterone are released in a pulsatile manner, it will be prudent to collect serial blood samples as well.

In conclusion, these swine represent the first genetically-engineered animal model to unravel the biological function of GNRH2 and its receptor in mammals. During pubertal development, GNRHR2 KD boars had smaller testes despite similar body weights. Transgenic males also tended to have reduced serum testosterone concentrations, independent of alterations in circulating LH levels. These results indicate that GNRHR2 is directly involved in the regulation of testicular steroidogenesis in swine. This

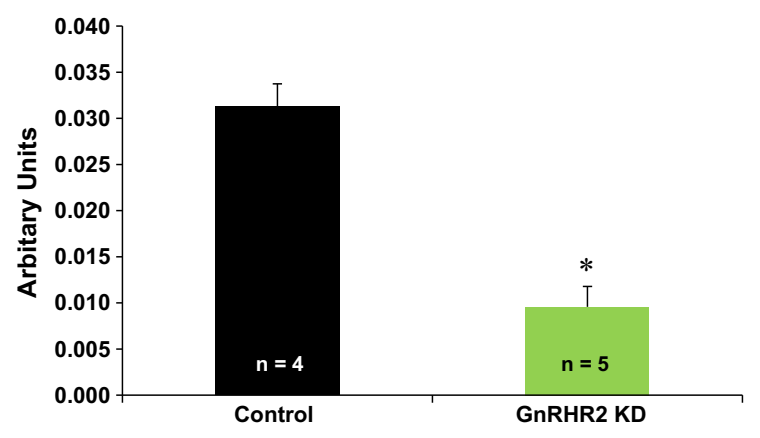

Fig. 3 Relative GNRHR2 mRNA levels are significantly reduced within the testes of GNRHR2 KD versus littermate control boars. Digital Droplet PCR revealed a $69 \%$ reduction in GNRHR2 mRNA levels (normalized to ACTB mRNA levels) in the testes of transgenic $(n=5)$ compared to littermate control $(\mathrm{n}=4)$ boars. Data are presented as the LSMEANS \pm SEM. $* P<0.001$ animal model will be used in future studies to elucidate the cellular mechanisms associated with localized regulation of testosterone secretion and define what consequences it may have for fertility in pigs.

Acknowledgements The authors are grateful to Sara Stauffer and Trevor DeVries for pig husbandry as well as Matt Snyder, Amy Voss, Jill Kerl, Scott Kurz and Bill Pohlmeier for technical assistance. The authors would like to thank Dr. J. Joe Ford for his advice and insight. The authors also express gratitude to Streck, Inc. (Omaha, NE) for use of the Philisa Thermocycler. This work was partially supported by National Institute of Food and Agriculture Hatch (NEB-26-199; BRW) and Agriculture and Food Research Initiative funds (2011-67015; CAL). A contribution to the University of Nebraska Agricultural Research Division, Lincoln, NE, 68583.

\section{Compliance with ethical standards}

Conflict of interest The authors declare that they have no conflict of interest.

Human and animal rights statement All animal procedures were approved by the University of Nebraska-Lincoln (UNL) Institutional Animal Care and Use Committee (IACUC). This article does not contain any studies with human participants.

Open Access This article is distributed under the terms of the Creative Commons Attribution 4.0 International License (http:// creativecommons.org/licenses/by/4.0/), which permits unrestricted use, distribution, and reproduction in any medium, provided you give appropriate credit to the original author(s) and the source, provide a link to the Creative Commons license, and indicate if changes were made.

\section{References}

Bailey TL, Hudson RS, Powe TA, Riddell MG, Wolfe DF, Carson RL (1998) Caliper and ultrasonographic measurements of bovine testicles and a mathematical formula for determining testicular volume and weight in vivo. Theriogenology 49:581-594

Bowen A, Khan S, Berghman L, Kirby JD, Wettemann RP, Vizcarra JA (2006) Immunization of pigs against chicken gonadotropin-releasing hormone-II and lamprey gonadotropin-releasing hormone-III: effects on gonadotropin secretion and testicular function. J Anim Sci 84:2990-2999

Brauer VM, Wiarda-Bell JR, Desaulniers AT, Cederberg RA, White BR (2016) Functional activity of the porcine Gnrhr2 gene promoter in testis-derived cells is partially conferred by nuclear factor-kappaB, specificity protein 1 and 3 (SP1/ 3 ) and overlapping early growth response 1/SP1/3 binding sites. Gene 587:137-146

Cederberg RA, Smith JE, McDonald EA, Lee C, Perkins AR, White BR (2015) Activity of the porcine gonadotropinreleasing hormone receptor gene promoter is partially conferred by a distal gonadotrope specific element (GSE) 
within an upstream enhancing region, two proximal GSEs and a retinoid X receptor binding site. Reprod Biol Endocrinol 13:45

Dann CT (2007) New technology for an old favorite: lentiviral transgenesis and RNAi in rats. Transgenic Res 16:571-580

Desaulniers AT, Cederberg RA, Mills GA, Ford JJ, Lents CA, White BR (2015) LH-independent testosterone secretion is mediated by the interaction between $\mathrm{GnRH} 2$ and its receptor within porcine testes. Biol Reprod 93:45

Dobrinsky JR, Johnson LA, Rath D (1996) Development of a culture medium (BECM-3) for porcine embryos: effects of bovine serum albumin and fetal bovine serum on embryo development. Biol Reprod 55:1069-1074

Gault PM, Morgan K, Pawson AJ, Millar RP, Lincoln GA (2004) Sheep exhibit novel variations in the organization of the mammalian type II gonadotropin-releasing hormone receptor gene. Endocrinology 145:2362-2374

Golding MC, Long CR, Carmell MA, Hannon GJ, Westhusin ME (2006) Suppression of prion protein in livestock by RNA interference. Proc Natl Acad Sci USA 103: 5285-5290

Hofmann A, Kessler B, Ewerling S, Weppert M, Vogg B, Ludwig H, Stojkovic M, Boelhauve M, Brem G, Wolf E, Pfeifer A (2003) Efficient transgenesis in farm animals by lentiviral vectors. EMBO Rep 4:1054-1060

McGrew MJ, Sherman A, Ellard FM, Lillico SG, Gilhooley HJ, Kingsman AJ, Mitrophanous KA, Sang H (2004) Efficient production of germline transgenic chickens using lentiviral vectors. EMBO Rep 5:728-733

Miao K, Guo M, An L, Xu XL, Wu H, Wang D, Wu ZH, Tian JH (2011) A new method to efficiently produce transgenic embryos and mice from low-titer lentiviral vectors. Transgenic Res 20:357-363

Millar RP (2003) GnRH II and type II GnRH receptors. Trends Endocrinol Metab 14:35-43

Millar RP, Milton RC, Follett BK, King JA (1986) Receptor binding and gonadotropin-releasing activity of a novel chicken gonadotropin-releasing hormone ([His5, Trp7, Tyr8]GnRH) and a D-Arg6 analog. Endocrinology 119: 224-231

Millar R, Lowe S, Conklin D, Pawson A, Maudsley S, Troskie B, Ott T, Millar M, Lincoln G, Sellar R, Faurholm B, Scobie G, Kuestner R, Terasawa E, Katz A (2001) A novel mammalian receptor for the evolutionarily conserved type II GnRH. Proc Natl Acad Sci USA 98:9636-9641

Morgan K, Conklin D, Pawson AJ, Sellar R, Ott TR, Millar RP (2003) A transcriptionally active human type II gonadotropin-releasing hormone receptor gene homolog overlaps two genes in the antisense orientation on chromosome 1q.12. Endocrinology 144:423-436

Neill JD (2002) GnRH and GnRH receptor genes in the human genome. Endocrinology 143:737-743
Neill JD, Duck LW, Sellers JC, Musgrove LC (2001) A gonadotropin-releasing hormone $(\mathrm{GnRH})$ receptor specific for GnRH II in primates. Biochem Biophys Res Commun 282:1012-1018

Neill J, Duck L, Musgrove L (2002a) GnRH II receptor is encoded in genomes of human, monkey, and pig but not mouse. Abstracts of the 84th Annual Meeting of the Endocrine Society, June 19-22, 2002. San Francisco, CA. Endocrinology; Abstract 74.9

Neill J, Duck L, Musgrove L (2002b) Potential regulatory role for GnRH II in gonadotropin secretion: molecular characterization of a GnRH II receptor in the pig pituitary. Abstracts of the 32nd Annual Meeting of the Society for Neuroscience, November 3-7, 2002. Orlando, FL. Proc Soc Neurosci; Abstract P1-97

Park F (2007) Lentiviral vectors: are they the future of animal transgenesis? Physiol Genomics 31:159-173

Pawson AJ, Morgan K, Maudsley SR, Millar RP (2003) Type II gonadotrophin-releasing hormone (GnRH-II) in reproductive biology. Reproduction 126:271-278

Roelz R, Pilz IH, Mutschler M, Pahl HL (2010) Of mice and men: human RNA polymerase III promoter U6 is more efficient than its murine homologue for shRNA expression from a lentiviral vector in both human and murine progenitor cells. Exp Hematol 38:792-797

Rubinson DA, Dillon CP, Kwiatkowski AV, Sievers C, Yang L, Kopinja J, Rooney DL, Zhang M, Ihrig MM, McManus MT, Gertler FB, Scott ML, Van Parijs L (2003) A lentivirus-based system to functionally silence genes in primary mammalian cells, stem cells and transgenic mice by RNA interference. Nat Genet 33:401-406

Stewart AJ, Katz AA, Millar RP, Morgan K (2009) Retention and silencing of prepro-GnRH-II and type II GnRH receptor genes in mammals. Neuroendocrinology 90:416-432

White RB, Eisen JA, Kasten TL, Fernald RD (1998) Second gene for gonadotropin-releasing hormone in humans. Proc Natl Acad Sci USA 95:305-309

Whitelaw CB, Radcliffe PA, Ritchie WA, Carlisle A, Ellard FM, Pena RN, Rowe J, Clark AJ, King TJ, Mitrophanous KA (2004) Efficient generation of transgenic pigs using equine infectious anaemia virus (EIAV) derived vector. FEBS Lett 571:233-236

Wise T, Zanella EL, Lunstra DD, Ford JJ (2000) Relationships of gonadotropins, testosterone, and cortisol in response to $\mathrm{GnRH}$ and $\mathrm{GnRH}$ antagonist in boars selected for high and low follicle-stimulating hormone levels. J Anim Sci 78:1577-1590

Zanella EL, Lunstra DD, Wise TH, Kinder JE, Ford JJ (2000) GnRH antagonist inhibition of gonadotropin and steroid secretion in boars in vivo and steroid production in vitro. J Anim Sci 78:1591-1597 